\title{
Through the Interviewer's Lens: Representations of 1960s Households and Families in a Lost Sociological Study
}

\author{
by John Goodwin and Henrietta O'Connor \\ University of Leicester
}

\author{
Sociological Research Online 14(4)6 \\ $<h t t p: / / w w w . s o c r e s o n l i n e . o r g . u k / 14 / 4 / 6 . h t m />$ \\ doi:10.5153/sro. 1971
}

Received:6 Apr 2009 Accepted:30 Jul 2009 Published: 31 Aug 2009

\begin{abstract}
In this paper we aim to use the interviewer notes from a lost sociological project (The Young Worker Project) to answer two broad, interrelated, questions: i) how was family life documented and represented by the researchers in their interviewer notes and ii) what does analysing interviewer notes in this way add to our understanding of families and households? The answers to these questions are considered in the context of a further question - why did the young worker research contain so much data on families and households when the research was concerned with young workers' early workplace experiences? In answering these questions we offer some insight into family life in the 1960s as documented by the researchers and locate Norbert Elias's young worker research within the context of the other large sociology research projects being undertaken at the time.
\end{abstract}

\section{Keywords: Interviewer Notes; Data Re-Use; Families and Households; 1960s Sociology; Norbert Elias}

\section{Introduction}

1.1 In this paper we re-examine data contained within interviewer notes from a previously lost sociological project to explore what insight the data has to offer about houses and homes, mothers, fathers and family formations some forty years ago. The lost project was the 'Adjustment of Young Workers to Work Situations and Adult Roles' (hereafter referred to as the young worker project) carried out by staff at the University of Leicester, UK, under the direction of the sociologist Norbert Elias, between 1962 and 1964. This research is very much a 'lost sociological project' as it has been ignored in most of the existing published works on Elias, except for one passing reference in a biographical introduction to Elias (Mennell, 1992). The project fell into obscurity as it ended in controversial circumstances (see Goodwin and O'Connor 2006a), failing to deliver on its original aims despite it being funded by the DSIR, and despite a significant amount of time having been committed to collecting data from the field. Instead, on completion of the fieldwork the research team resigned from the project and the interview transcripts were simply boxed up and stored away. Ten years later a small sub-sample of transcripts were analysed and published in the book 'Young Workers' (Ashton and Field, 1976) but the bulk of the data and interview booklets remained untouched, their promise and potential ignored. In 2000, almost forty years after the data collection originally took place, we rediscovered 851 interview booklets and project papers stored in an attic office. Each interview booklet represented a detailed account of an individual experience of the school to work transition along with extensive interviewer notes in which the researchers recorded in detail their experiences of the interviews and their views on the respondent's home and family.

1.2 The aim of this paper is to use this data to answer two broad, interrelated, questions: i) how was family life documented and represented by the researchers in their interviewer notes and ii) what does analysing interviewer notes in this way add to our understanding of families and households? Neither of these questions is mutually exclusive, but instead they are intertwined in the interviewer notes. However, these questions do bring together two interlinked themes that have interested us for some time. First, an interest in community studies and post Second World War sociological research, particularly from the 1950s and 1960 s, and second, an interest in the process of reusing qualitative data from past sociological studies. 
also useful to acknowledge some of the other sociological research projects from the early 1960 s as it is evident that the young worker project has much in common with these. There are clear overlaps with community studies and it has similarities with other classic studies such as The Established and the Outsiders and The Affluent Worker in the Class Structure. Initially we approached the transcribed data from the re-discovered interviews with some trepidation given the sheer breadth and depth of the topics covered. Indeed, we asked ourselves why was it that a project ostensibly about early workplace experiences generated so much detailed data, especially in the interviewer notes, on households, home and family life? There are numerous possible reasons as to why such detail was included; however we feel that the answer lies within two interrelated explanations. First, for us the interview data and research design suggests that the young worker project had much in common with, or harked back to, earlier community studies. The young worker project was not simply a study of young workers in Leicester and it did not simply explore one relationship or one aspect of their lives. Instead the young worker project was a multifaceted and complex research project covering the interrelationships (or figurations in Eliasian terms) of home and family, relationships, education and school, work and employment, income and expenditure and leisure time amongst other things in Leicester. In its design this reminds us very much of Bell and Newby's (1978) approach in their book Community Studies which suggests that to be considered as a community study such research must 'examine the interrelationships of social institutions in a locality' (Bell and Newby, 1978:19).

1.4 If the young worker project is not a community study in any conventional sense it was certainly influenced by The Established and the Outsiders (1965) community study that Elias and Scotson were writing up at the time. From the archival materials it is clear that the writing of The Established and the Outsiders was largely undertaken at the same time as the research design and fieldwork on the young worker project and Elias managed both remotely from the Sociology Department at the University of Ghana. Indeed, Elias, whilst working in Ghana on both projects, made numerous references to The Established and the Outsiders in his correspondence with llya Neustadt (for example see $18^{\text {th }}$ January 1963 and $13^{\text {th }}$ March 1964) alongside discussions of the approaches to be adopted in the young worker project by the project team. There is little doubt that Elias's experiences of working with John Scotson during the early 1960s influenced his approach to studying young workers and the young worker project in turn (as with The Established and the Outsiders) provided Elias the vehicle through which to explore themes developed earlier in Über den Prozess der Zivilisation (1939) reprinted later as The Civilising Process (1994). As Crow suggests

Elias and Scotson's (1965) The Established and the Outsiders stands out in this respect, being (amongst other things) an illustration of the analytical power of the conceptual framework contained in Elias's work on the civilizing process. What Elias calls the 'defunctionalization of communities' (Elias 1974: xxix), the process whereby individuals become less completely dependent upon their local social networks, is shown in this study to be quite compatible with the continuing existence of local social exclusivity. (Crow 2002: 2.3)

1.5 A second, related, explanation can be found in Elias's own sociological position. The reason why families and households were important to the young worker project was that for Elias the project was not about work per se but instead the 'work situation'. He argued that the many problems faced by young people in entering work rarely sprang from work in isolation of other situations. Instead, to understand the transition from school to work necessitated an approach that examined the interrelationships and interdependencies that bound people together and how these interdependencies emerged and changed over time. Simply examining work would not provide the insights Elias sought and in Eliasian terms it is not useful to separate out 'home', 'work', 'family', 'education' and even 'community' as if they were different units or levels of analysis.

Instead of attempting to gain from the exploration, and particularly from the measurement of artificially isolated part units and their purely additive assembly a picture of the larger composite unit so that analysis leads the way, one has to proceed in an almost opposite manner. Analysis yields the lead to synthesis. The emergent image of the larger composite unit...helps to show how the provisionally isolated smaller part units fit into, and are determined by, the more or less closely-woven larger nexus of functional interdependencies of which they form a part. (Elias 1974: xxxiv)

1.6 However, as we have discussed more fully elsewhere (see Goodwin and O'Connor 2006a), Elias's approach to the young worker project was not wholly compatible with the methodological and theoretical concerns of the research team in Leicester who had to operationalise the research design. For them the research was about work per se rather than all of these 'surrounding' issues and this conflict lead to the demise of the research. Such differences in approach are also highlighted in the preface to The Established and the Outsiders in which Elias and Scotson celebrated the fact that their research in Winston Parva was underpinned by the opportunity to follow clues as they emerged which in turn helped 'counteract the rigidities of any set ideas we had as to what was and was not significant in the study of community. It enabled us to scan the horizon for inconspicuous phenomenon that might have significance' (Elias and Scotson 1965: x). This was written at a time when the fieldwork on the young worker project was in serious jeopardy of collapse and the research team fully at odds with Elias as to how the study should progress. Elias's view here is in stark contrast to the hypothesis testing/ positivistic model being advocated by the research team back in Leicester who, Elias suggested, were 'simply trying to look for causal relationships between the different aspects of the sample' (Goodwin and O'Connor 2006a: 162). However, as suggested above, Elias perceived things very differently and was not interested in such 'billiard ball causality' as he wanted to understand the whole configuration.

1.7 We can also learn a great deal from the analysis of other archived projects, and especially Savage's (2005) work on the Affluent Worker in the Class Structure project. Savage highlights for us some overlap in the concerns and approach between the Affluent Worker in the Class Structure research and the young 
worker project. At one level this is no real surprise as those working on the young worker project knew members of the Affluent Worker project team via sociological networks and in the 1950s Goldthorpe had worked with Elias at Leicester. However, Savage's (2005) analysis reveals a subtler basis for a possible overlap between the two in that the overall orientation to the research in both projects shared some similarities. Both, for example, contained a great deal of qualitative data that remained unused but which linked back to a more inductive research style. Like Elias's interest in Leicester, Savage highlights that the archived data from the Affluent Worker project 'amply show their interest in Luton as a 'community'...each of the household interviews has full notes about the décor of the house, its arrangements and furnishings, which indicate a much more ethnographic interest' (Savage 2005: 39). Such concerns feature heavily in the young worker project. Perhaps most importantly, Savage (2005) hails Goldthorpe and Lockwood's 'tripartite research strategy' adopted in the Affluent Worker project as a new departure for social research. Yet the suggestion that research should draw 'specifically on sociological theory (which was hence concerned with sociological, rather than social problems)' (Savage 2005: 38) is also Eliasian and is fundamental to the young worker project. Indeed, Elias (1987) is very critical of the narrowing of sociologists' attention and interests to the solving of immediate, and largely short-term, 'social problems' and argues that this dominant trend in post second world war sociology, whilst not unproductive methodologically, has yielded little real insight (Elias 1974):

the immediate present into which sociologists are retreating... constitutes just one small momentary phase within the vast stream of humanity's development, which, coming from the past, debouches into the present and thrusts ahead toward possible futures. (Elias 1987: 224).

1.8 Elias's (1987) critical work on the retreat of sociologists into the present brings us to our second theme of data reuse. Elias offers a further promise for any sociologist interested in re-using data from classic or historical studies in that he strongly advocates a turn away from this 'retreat into the present' (Elias 1987: 223). The re-use of data from past studies reverses this trend somewhat and reveals the promise and provides the possibility of long-term investigations into the continuities and changes in the history of societies and individuals (Elias 2001:102). This is not so much the 'appeal to history' that Savage (2005: 5) highlights, but more of a recognition of the centrality of time and, more particularly long-term social processes, to sociological analysis. Indeed, the value of revisiting data from past projects is then wellrecognised and one of the most important contributions that secondary analysts can make is to document social change over time. Data re-use enables the researcher to examine longer-term 'diachronic change' (Elias 1974: xv) and the possibility of using a contemporary empirical/theoretical lens to interrogate the veracity of past predictions and trends. What re-use also offers is an opportunity to revisit the past through the snapshots of another period. Interviewer notes from earlier studies provide not only a documentation of life in another era but also a window to the preoccupations of research teams at that time.

1.9 However, whilst the debate on the issues emerging from the archiving of data and the reanalysis of secondary, qualitative data are well documented in the literature (Hammersley, 1997; Laub and Sampson, 2003; Fielding, 2004; Heaton, 2004; Savage, 2005; Goodwin and O'Connor 2006), less attention has been paid to the secondary analysis of the documentation associated with research projects often archived along with the original data. Project documentation can include field notes and interviewer notes, seen by some as being central to the process of reanalysis. Dale et al. (1988) for example, argue that the contemporary researcher cannot effectively reuse data unless s/he has access to the accompanying project documents. This is even more important in the secondary analysis of qualitative data as, if the secondary analysis is to be meaningful, a full understanding of the data collection process is essential (for a fuller discussion of this see: O'Connor and Goodwin, forthcoming). Yet, with the exception of Savage (2005) few researchers have made use of such historical documents as data sources even though field notes and interviewer notes can provide illuminating insight in to the methods and processes of past research projects.

1.10 Before the discussion moves on to consider the themes and findings emerging from the interviewer notes, it is important to offer a brief comment on the background to the original research and the social, economic and housing context of Leicester in the 1960s.

\section{The Young Worker Interviewer Notes: Context and Promises}

2.1 The young worker project was originally designed to explore the transition from school to work in an English provincial city - Leicester. Over forty years later the data provides a fascinating insight into the lives of young people and their families in 1960s England, highlighting both continuities and changes, with each interview booklet containing 82 questions split across 5 sections - Work, Family and Expenditure, Leisure, School and Work, and General. Indeed, although originally designed to examine the problems which young male and female workers encounter during their adjustment to their work situation and their entry into the world of adults' (Young Worker Project 1962: 2), the data illuminates many aspects of family life from this time and provides us with a great deal of insight into issues such as parent/child relationships, the allocation of money in the household and so forth. As such, with permission from the some of the surviving research team, and from the Norbert Elias foundation, we devised a scheme of research that would involve a re-analysis of the 1960s data and follow up interviews with those respondents we could trace.

2.2 There were a number of important features of the data collection process. First, are the detailed interviewer notes included at the back of each of the original interview booklets (see Figure 1). As well as completing the interview booklets as 'verbatim' as possible the interviewers were advised by Elias to reflect fully on the atmosphere of the interview and their 'general impression from the interview noting any significant issues connected with work, family or leisure'. The interview notes, written up at the time of the interview or shortly after, contain a rich source of data and, in their own way, offer a very vivid picture of households and family life in 1960s Leicester as seen through the interviewer's lens. 


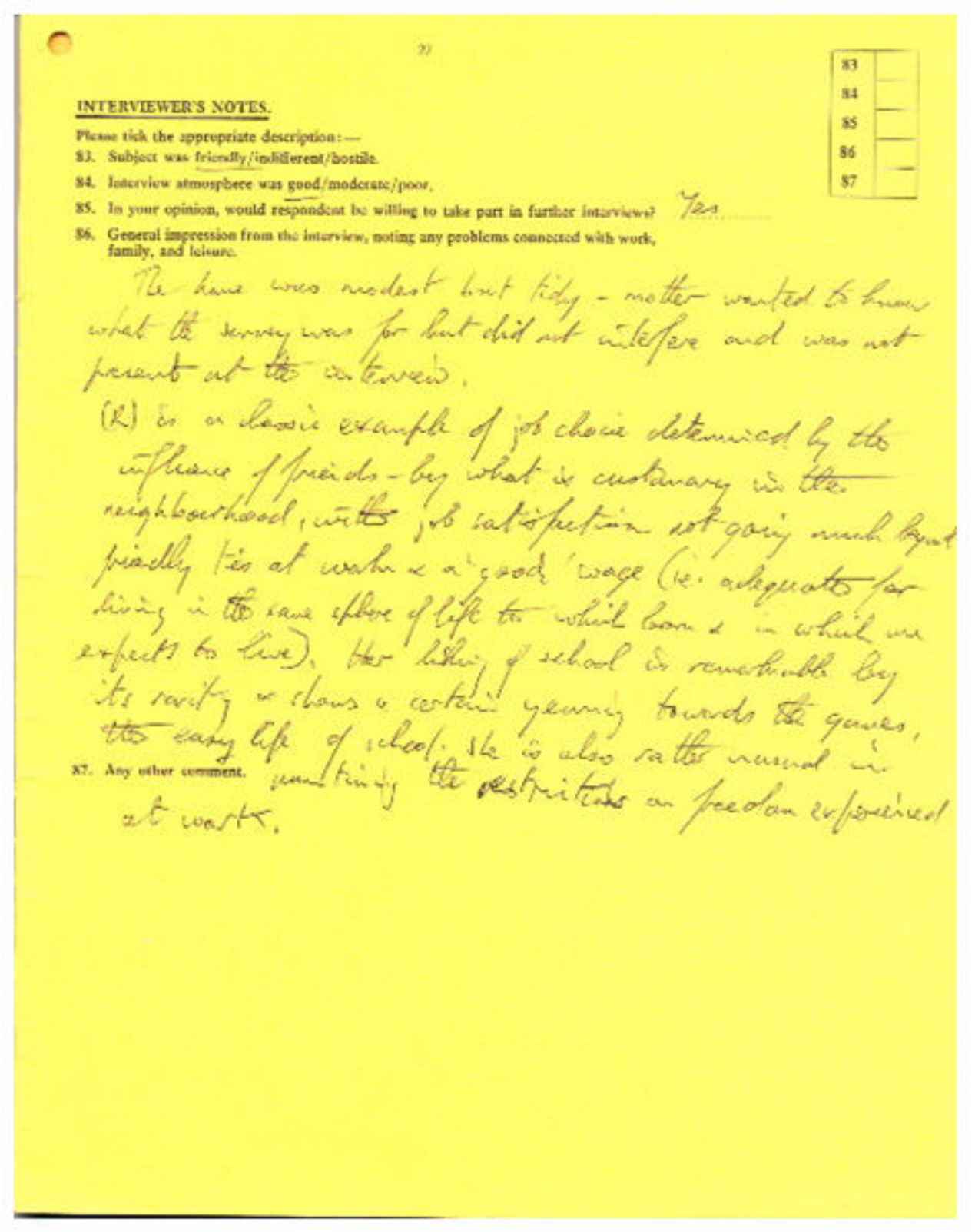




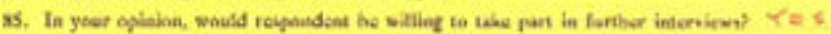

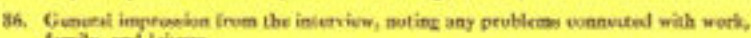
limily, and leisere.
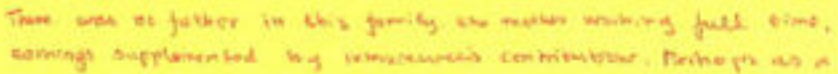

2.3 A second important feature was the composition of the researchers in the field. The research team itself comprised of five main researcher officers, three male and two female, all of whom had been educated to degree level and could be considered to have middle class backgrounds. In addition a number of graduate students and final year undergraduates carried out some of the interviews. The correspondence accompanying the project suggests that llya Neustadt, Head of Sociology at the time, had clear views on the suitability of students for further study and participation in this research project. Those selected were largely male, were deemed to be high achievers and the majority had taken Elias's theoretical courses during their studies at Leicester. The composition of the group of interviewers suggests a fairly homogenous middle class group with strong theoretical and empirical training whose experiences of education and work were very different to those of the respondents they interviewed. Such homogeneity undoubtedly impacted on the research process and the observations made and noted during each interview.

2.4 Third, it is important to understand the purpose for which this data was collected and the audience for whom the notes were intended. For example, the interviewer notes were collected to support and contextualise the analysis that Elias and the research team planned to undertake once the data collection stage was complete. However, as we have seen above, the actual nature and aims of the research were contested and such divergent views led to some of the research team offering detailed ethnographic quasivisual descriptions of homes and respondents. Indeed, whilst the level of detail offers a great deal of value to the research the interviewers are perhaps far more candid than contemporary research practice would allow. They offer a great deal of subjective and sometimes judgmental comments on the interviewee's, the interviewee's families and their households. For example, one interviewer wrote:

The pattern in this family, at least for the female is to marry early and produce regularly. Respondent therefore, seems to regard work as something to put up within between school, staying at home and marriage (though she didn't have a boyfriend). The family was poor yet seemed extremely happy and very closely-knit...the house was so small and the family so numerous. The Mother was the power-house, a great fat woman she sat there surrounded by numerous of her numerous children, Father sat eating his dinner off his lap in front of the television, Sister sat dangling a new baby, scuffles with dogs and brothers stripping off - in 
the middle of the room for a wash in the šcullery, all interrup̌ted the flow of the interview.

2.5 The impact of these three key issues: the inclusion of a guided interviewer notes section in the interview booklet; the composition of the research team and the intended audience for the notes, is revealed more fully in the consideration of the data below.

2.6 We have written about treating such interviewer notes as 'data' more generally elsewhere, including the ethical and methodological issues that the secondary analysis of such qualitative data generates (see Goodwin and O'Connor 2006b). However, it may be worthwhile to briefly discuss some of the methodological and ethical issues surrounding the use of interviewer notes as data. There are a number of benefits of re-analysing interviewer notes. For example, access to fieldnotes can provide essential contextual information about the research as whole; interviewer notes may reveal factors that could have affected the data collection process such as sources of bias; and interviewer notes provide a rare insight into the experiences of collecting data in the field. As Savage (2005:3) suggests, 'Given the normative character of much social science methodology texts, where the focus is on how researchers should conduct their research, rather than how they actually went about their research, this offers an important, much under utilised, way of developing our methodological understanding'. The re-analysis of interviewer notes provides insight into the research process and makes the invisible visible. However, despite these possibilities, the secondary analysis of the interviewer notes raises a number of ethical and methodological concerns - including confidentiality, anonymity, the researcher-researched relationship and the possible problem of 'auditing'.

\section{The Local Context: Leicester in the 1960s}

3.1 There have been numerous accounts of the development of the city of Leicester, from its Roman roots to its dominance as a manufacturing base in the English Midlands (see Brown 1970; Pye 1972). Yet there are few accounts that explore the history of the city in terms of its families and households - with perhaps the exception of Pye (1972) who reflects on this briefly. However, what is without question is that, for much of the twentieth century, Leicester has been synonymous with three industrial manufacturing groups: engineering, textiles and footwear manufacture, which, at their peak in the 1960s, employed over 140,000 people. With unemployment in Leicester during the 1960s at around 1 per cent and the high demand for labour, and the availability of relatively well-paid manufacturing jobs, the needs of the industry were met by a large amount of inward migration. In the early 1960s 27,730 moved to the city from other parts of the UK and Leicester's ethnic minority population grew rapidly, with migrant workers arriving from South Asia, the Caribbean and East Africa. This period was also marked by an 'outward growth' of the city and a considerable expansion in the number of private houses and municipal housing developments (Pye, 1972: 456). As Pye suggests the 'growth of Leicester has taken place in a radical pattern, thus forming four concentric rings: an inner core, a middle nineteenth century ring, an outer inter-war ring, and, finally, a postwar fringe (Pye 1972: 456). The respondents in the project were spread amongst these four concentric rings but with significant concentrations in the city centre, the post war social/municipal housing estates of New Parks, Braunstone, Eyres Monsall and Saffron Lane and those areas on the fringe of Leicester including the areas of Thurmaston and Birstall. However, in the context of our data presented below, it is also important to note that there was a very marked difference in the social and economic conditions of these areas - with households in the city centre and on the municipal housing estates experiencing higher levels of social and economic deprivation as compared to those living in the private housing developments in the 'post war fringe' where the residents tended to be a great deal more affluent. Indeed, the centre of Leicester was still subject to slum clearances in the early 1960s with 6390 dwellings being identified as sub-standard in 1963 alone (Leicester City Council 1963). As such, this would mean the interviewers would encounter a wide variety of homes and households during their visits to interview the young workers. This would have included homes on a continuum from well-furnished and affluent to those homes with few furnishings and that were relatively impoverished. They also encountered a wide variety of respondents and families, from the established middle class families of the Leicester suburbs to the working class families living on the municipal housing estates. They would also have encountered the first established ethnic minority groups in Leicester as the interview sample included young Italian, Polish and Irish workers.

\section{Interviewer Reflections on Homes and Housing}

4.1 As suggested above, the interviewers would come to know the areas of Leicester very well as all respondents were interviewed at home. The reason for the interviews being carried out at the home address was primarily a practical one. The respondents had all left school and therefore could not be interviewed at school and, as interviews took place after work, in the early evening, then home was the most logical location for the interview. However, undoubtedly, the opportunity for the interviewees to view the circumstances of the respondent's home and family life also played a role. The project team were interested in examining the impact of home and family life on the transition process and, for this reason, paid close attention to the home environments and family background of the young workers. Indeed, this variety of locations and the mix of more affluent 'garden style' suburbs with much poorer (and less socially desirable) inner city and municipal housing estates were recorded by the interviewers in their notes. Without doubt, the interviewers interest in the locality and social geography of the area was influenced by the hold of the field of community studies in sociology at this time (e.g. Young and Willmott; 1957; Stacey, 1960). Given this historical and methodological context it would have been difficult for the researchers not to acknowledge the significance of the home and family background of respondents.

4.2 Immediately one can see the impact of the interviewer's lens and it is clear from the data that the researchers already had very strong ideas about what constituted a 'good' area or location in which to live and those areas that they perceived to be less desirable. These perceptions, as documented in the interviewer notes, were often underpinned by very strong class biases, with the researchers apparently very keen to differentiate the housing conditions of the working class from those of the middle class respondents. For example, when reflecting upon interviews with middle class young workers, the 
A very large house in a good residential area of Leicester and every indication of great material prosperity.

A comfortably, clean home at the edge of a housing estate but not actually in it conversations with someone on the other side of the road revealed that the block of people considered themselves different from and rather superior to the estate dwellers. It is what one would call a lower middle class area - certainly the respondent would be classified as such by his occupation, dress, speech and by his peer-group ties which are with one other person particularly i.e. there is no gang membership.

4.3 In the first quote, the interviewer clearly has an idea of what is good and respectable - i.e. large house, material prosperity, etc. In the second quote the interviewer makes the point that whilst the respondent lived close to one of the city's housing estates he did not actually live in the housing estate and reports the residents' perceptions of themselves as 'different'. This difference is then also linked very clearly to speech, dress, occupation and friendship groups as signifiers that this respondent was middle or lower middle class rather than working class. However, this contrasted with the interviewer notes for those respondents who lived in the inner city or in the municipal housing estates. Here the respondents tended to have their localities described in more detail and, in the main, more negatively. For example
Respondent's home is in a row of terraced houses in an unadopted road. All the houses in the row are badly cared for. Inside similar - rather grubby wallpaper, poor furniture crowded in. Yet jobs would have indicated a large family income and plenty to spend on material possessions.

The family live in a low saleable value area, where many of the larger houses are let off in rooms to 'coloured' immigrants. Respondent and family spend weekends in a bungalow in the country a few miles out of Leicester...The house was comfortably furnished, but the furniture was old.

Small pre-war terraced home, rather squalid district, many coloured families living nearby.

4.4 Housing type was clearly an important focus for interviewees and seemed to be used as a way of understanding the respondents place in the social structure of the city, distinguishing people 'from one another by their strength in the housing market' (Rex, 1967, quoted in Bell and Newby, 1978: 205). This approach to understanding housing types classified housing into three 'normal and desirable' types; 'the captains of industry go to classy detached houses in inner suburbia, white collar workers move to inter-war semis and the working classes move to council houses'. A fourth category comprises the slum areas of inner-cities, inhabited by those 'left behind...together with deviants and recent immigrants to the city' (Bell and Newby, 1978: 205). The interviewers in the Leicester case seemed to use such classifications to determine the respondent's class and family background and accordingly they had a preoccupation with not only the location of the respondents' homes but also the value and the saleable value of their homes. Such an approach to understanding the social position of respondents demonstrates a lack of insight into the lived realities of these young people; the homes in which they and their families were often rented and not theirs to sell. Harris et al. (2006:3.6), writing about the city of Swansea in South Wales during the same time period, comment that 'you would, if you were working class in Swansea in 1960...almost certainly have rented your living accommodation'.

4.5 Indeed, this was a period during which local housing was being transformed due to government policy which aimed to improve the quality of housing. This was achieved by the implementation of slum clearance programmes which took place across the UK, whilst at the same time council estates were built on the periphery of cities and towns. Nevertheless, a number of the interviewees still lived in houses which the interviewers described as slum dwellings. These were often overcrowded and lacking in basic amenities, far removed from the 'post-war domestic ideal' (Crow and Allan, 1990), illustrating that for many families improved standards of living remained an aspiration:

The boy to use his own phrase was rather "miserable faced" but friendly. He came from a large family who lived in one of the decrepit slum dwellings in New Walk. The front room was filthy dirty, smelt, and wallpaper was peeling off or had already been torn off. There was no carpet and very little furniture apart from a large T.V. set standing in the corner. The children were filthy dirty but the mother was a very pleasant woman, shabbily dressed.

At home - mother and son live in one room in a small 6 roomed house [unpassaged] mother sleeps on settee, boy has camp bed which folds up during the day. The rest of the house is occupied by a family of 8 - one child in family suffers from acute asthma and has to have a room to himself. There is difficulty preparing meals as there is only one small kitchen for everyone's use. The boy feels keenly about the way they are living said they should have a proper home with a key to their own door.

The boy and myself sat in the corner of the living room which was occupied by six other adults all carrying on conversation with each other and a young baby was being bathed and crying in the centre of the room. A large corner of the room was made into a cage housing a monkey and a cat and a dog were wandering around. A TV set blared forth all the time.

4.6As illustrated in the previous discussion much emphasis was placed by the interviewers on aspects of social geography, the location of the home and the classification of the housing stock. The interviewers also had a valuable insight into living conditions at the time and frequently gave very detailed accounts of 
the interiors of the homes and evidence of material wealth, for example ownership of domestic appliances. In particular those homes which either did or did not 'fit' the 'post-war domestic ideal' (Crow and Allan, 1990) were described in some detail.

Not much money spent on this home, judging by furnishings, they live rough- e.g. tin of meat for his tea was on table when I visited.

This was quite the most squalid home I have been in for years. The whole place was dingy and filthy. I sat in the living room to do the interview, I rather suspect it was the only habitable room downstairs. [Respondent's] mother sat watching whatever happened to appear on I.T.V. during the time I was there and the only heating was from a paraffin stove.

The house is untidy and the mother insisted that "we are informal here". This was born out by the soiled newspapers on the table - remnants of a fish and chip supper. Also by the insistence that I drop my cigarette ash on the floor.

An extremely bright and well furnished home inside. Small terraced house brightly painted outside, stands out from the others in the street.

They lived in a small house that was very well (if not tastefully) furnished and very clean and the boy seemed to own a number of luxury goods ranging from a car to a tape recorder. Although his mother bought some of them he had also bought her some domestic appliances.

4.7 The interviewers provided detailed comments on evidence of the rise of the consumer society. This is perhaps not surprising given that during this period standards of living were improving for many families and, as Goldthorpe et al. (1969:8) suggest:

the possession of various kinds of consumer durables ... was evidently becoming fairly general, while increasingly too manual workers were invading the hitherto almost exclusively middle-class preserves of car and house-ownership ... one defining feature of the working class, as traditionally conceived, was fast becoming obliterated: that is, its clearly inferior position in terms of economic resources and consumer power'.

4.8 The interviewers tended to comment on ownership of material goods such as cars, televisions and domestic appliances and related these to other signs of material wealth, 'middle class behaviour' or $\mathrm{good} /$ poor taste:

Private, semi-detached house which was full of expensive material goods (thick carpets, fridge and other kitchen equipment, expensive furniture, etc.) in real mass culture taste.

Family seems to be enjoying enormous prosperity,

A well kept comfortable home lacking nothing in modern amenities.

The home was large and comfortably furnished. The sitting room was fitted with a hi-fi and they owned a Volkswagen car. Respondent was really 'with it' when I first met him, wearing a Beatles collectors suit.

4.9 The possession of consumer goods was not though an automatic indication that the families had any wealth or were comfortably off financially.

It was a large family and although they possessed a radiogram and washing machine, the family lived relatively in sheer squalor. This and the ownership of the washing machine may be due to the fact that the mother worked long hours as a domestic help at the remand home, although all 6 children were still at school

The home he lived in contained 2 T.V's, an automatic dishwasher, a refrigerator, a washing machine and gadgets in the kitchen. But in spite of all this, the family lived in utter squalor.

\section{Mothers, Fathers And Family Formations}

5.1 Whilst the preceding discussion focused primarily on representations of the respondent's home environments, these descriptions touched upon other factors such as the role of parents and siblings, the physical characteristics and personality traits of parents and the nature of the relationships between parents and children. This emphasis may well reflect the dominance of 'social-psychological theories of the day' (Savage, 2005: 15) but it also reflects Elias's concern with, and interest in, considering the role of interrelationships between home, school and work.

5.2 The interviewer comments on family life, in particular the descriptions of mothers, fathers and complex family formations, are fascinating and are very much influenced by the time period in which the interviews took place. Comments on mothers for example, tended to focus on their housekeeping skills (or perceived lack of such skills) and there was clearly an expectation that the primary role of the mother should be ensuring that the home was run efficiently.

5.3 This, in part, can be explained by the influence or 'hold' of the male breadwinner model of family life in Britain at this time. The traditional 'male breadwinner model family', whereby women are committed to fulltime motherhood and responsible for domestic and unpaid duties and men have responsibility for financial provision has formed the basis of government policy and has shaped ideas of masculinity, femininity and 
gender roles for much of the post-war period (Crompton and Harris, 1998). The model has also led to the notion of an 'idealised mother' who stays at home and dedicates herself to childcare and domestic pursuits rather than participating in the labour market. Such an approach does not accommodate the idea of a woman being able to fulfil the task of motherhood whilst simultaneously taking employment outside the home and promotes a way of life which has never been realistic for many women.

5.4 However, it was this ideal which was supported by government policy and permeated public opinion throughout most of the twentieth-century. This is reflected to a great extent in the descriptions of mother's roles in the interviewer notes. The interviewers were critical of mothers who did not appear to have high standards in housekeeping and/or personal appearance. Cleanliness of the home was frequently commented upon and used as a marker of respectability (Innes and McKie, 2006). They appeared to expect to see evidence of 'female domestication' (Harris et al., 2006: 2.5), particularly given that, as illustrated earlier, 'new household technology was held out to offer liberation from the drudgery of housework' (Crow and Allan, 1990:23):

The R's mother was present for the whole interview. She was very shabbily dressed and untidy as was the rest of the home.

\begin{abstract}
Mother an extremely house proud woman fussed around with a duster all the time I was interviewing the boy altho' there was no dust anywhere. Obviously she didn't intend the boy should tell me anything she didn't know about.
\end{abstract}

Mother was a tired woman, on whom the responsibility and effort of bringing up a family had taken its toll. Her and $\mathrm{R}$ appeared to live together in harmony, he was helping her in the garden, lighting a bonfire when I arrived.

5.5 The strength of influence of the male breadwinner model was also evident in the descriptions of fathers and the interviewers held very strong traditional notions about fathers as providers or breadwinners. The comments illustrate that they held very strong views, based around this model, and where the behaviour of fathers did not conform to this traditional pattern they were criticised. For example, where families were lacking in material wealth or appeared to be living in poverty, fathers were subject to considerable criticism in the interviewer notes:

[the] Respondent's concern over the shortage of money in the house was justified as far as the kitchen was concerned. I don't know how much father earned but the condition of the kitchen indicated financial hardship in the home.

Family appeared disciplined, 2 little girls present never spoke during interview, but relationship with mother seemed happy. Father probably very much the boss. Father at home but not seen, voices toward when replying to question about staying out late at night.

There was no father in this family, the mother working full time, earnings supplemented by interviewee's contribution. Perhaps as a consequence of this situation the house appeared rather bare and neglected. Nevertheless there appeared to be a great bond of affection between the members of the family, in particular between the mother and the interviewee who met on equal terms.

5.6 Interestingly the interviewer notes also contained a great deal of commentary on the personality and physical characteristics of the mothers, despite these not being at all relevant to the research, the researchers described the mothers in quite vivid terms:

Mother a fat blousy woman and home grubby and not very well cared for.

Mother was present through out a big fat jolly woman in grubby overall - seems very happy person with very good relationship with all family.

5.7 A similar preoccupation with the physical appearance of parents, in particular working class parents, is apparent in Jackson and Marsden's (1966: 64) work:

'many husbands were well-shaven, red-faced men, rather small in stature. They had hairy arms, stubby nails and greying hair. Often their wives, though slightly younger, had been grey for some years ... The wives nearly always seemed much larger. They were mostly fat and bulky with thick arms and legs'.

5.8 Such vivid and derogatory descriptions, so at odds with contemporary social research practice, seem to have been commonplace amongst researchers during this period. There are a number of explanations for the tone of these comments. First, they can be seen as being simply a reflection of the concerns of social researchers during this period. It is important to acknowledge that these fieldnotes are bound by the historical context. As Savage (2005:21) has argued this research took place during a period when sociological research reflected the:

'tradition of Victorian social work, concerned with evaluating the moral capacity and household circumstances of particular families ....[and] the researchers were quite happy to pass judgements about the respondents'.

5.9 Second, the research team were specifically asked to comment on the social and family background of the respondents as this was seen as having a bearing on the experience of the school to work transition. Third, the fieldnotes that we have accessed were intended for the use of the project team and not for a 
wider audience and this fact would certainly have impacted on the style and tone of the fieldnotes.

5.10 Much of the literature around family formation and structure focuses on the extent of social change in the post-war period. The view that family structures have become more complex through increasing rates of cohabitation, separation and divorce and the rise in the numbers of single parent families and families with step-parents is well documented (Smart and Neale, 1999; Finch, 2007). However, it has also been argued that 'diversity and plurality have always been a feature of family relationships' (Gillies, 2003:3) and the extent of change in family structures in recent decades has been over-emphasised (Crow, 2002). Indeed, our interviewer notes highlight a range of complex family living arrangements including multigenerational families living in one household, single parent families and teenage parents. This suggests that in the early 1960s 'a cosy romanticised view of family as a secure and supportive network centred around 'Mum" (Gillies, 2003:6) was not always the reality:

There are obviously many problems at home connected with mother's desertion of family. He made it very clear he did not want to talk about it, showed signs of bitterness and resentment towards mother and maybe this is partly why he apparently has no girlfriends of own age. Did not seem very interested in either his brother or sister and so apparently has close relationship with father in the family...Grandma seems to be regarded by family purely as housekeeper and father trying very hard to be both mother and father to children - youngest came in sobbing from play and only father made any attempt to console and find out what was wrong. From everyone's extreme sensitivity about mother, [it] would seem that her desertion is fairly recent, maybe related as partial cause or result of move from Braunstone about 2-3 years ago.

The first thing to strike me about this boy is his highly complicated home life, his moves from parents to grandparents (their adoption of him and acquisition of step brothers) and then living with each of them in turn on the deaths of the former. And added to this the fact that both step-brothers are publicans, which usually results in disconnected domestic living anyway.

The respondent and his father were obviously very close, respondent appeared to be very young and rather immature, but he was very friendly. Both were frank and obviously wanted to be as helpful as possible. Respondent did not seem to go out much, although father was definite about the lack of restriction. The respondent and his father had lost the woman of the house, the wife, just before Christmas...father gave me the impression that respondent was the youngest, by several years, and was born late in life and was rather doted on by his mother.

The family relationship was most complicated and I thought it not advisable to enquire too deeply into it. This much I gathered. The house belonged to grandmother. The father of the two brothers had either died or disappeared. Mother was definitely alive and had left the house within the last 2 years. Brother was also married and had a 7 year old son but his wife was no longer living with him. Instead there was someone called ${ }^{\star \star \star \star \star \star \star}$ around the house.

5.11 As these quotes illustrate there was evidence of complex and non-standard family and household formations in this study. However, such households constituted the exception rather than the 'norm' and it is possible that the interviewers made extensive comments on such cases simply because such households were unusual at the time and therefore warranted a special note (Wolfinger, 2002). What is striking here is that the interviewers were clearly quite surprised by the structure and composition of some households and it seems unlikely that such patterns would come as a surprise to the contemporary researcher who may be more likely to expect to find complex household structures.

\section{Conclusion}

6.1 We began this paper with the aim of using this data to answer two broad, interrelated questions: i) how was family life documented and represented by the researchers in their interviewer notes and ii) what does analysing interviewer notes in this way add to our understanding of families and households? The answers to these questions also had to be considered in the context of a further question - why did the young worker research contain so much data on families and households when the research was concerned with young workers early workplace experiences? We have argued that the answer to this lies within Elias's own sociological position and within the influences that past community studies or other sociological research from the time may have had on the processes of research design and data collection. Whether there was a direct influence or whether the research team were influenced by the general sociological milieu of the period is hard to say, but the parallels and overlapping concerns are obvious - with Elias's young worker project reflecting Goldthorpe and Lockwood's concern for research underpinned by sociological problems rather than social problems. As we have suggested above, Elias was not interested in studies that concentrated on only one aspect of social phenomena but instead saw the interconnections between community, education, work and family as holding the key to understanding the adjustment young workers made in the transition from school to work. Although ostensibly about young workers, when we set the young worker project in the context of the broader Eliasian canon, it is easy to understand why the family features so prominently in this lost project.

6.2 What is also clear, as others such as Savage (2005) have found, is that the interviewer notes are not only essential for the secondary analyst but they are also a valuable and rich data source in their own right that should be subjected to re-analysis. Although as we have seen, the focus of the young worker project was not primarily concerned with family life, re-analysis of the interviewer notes reveals detailed accounts of family structures and family relationships. As such, the data here does indeed shed light on the interviewer's lens with regard to families and households in the 1960s and reveals how differently family life 
was documented and represented by researchers of that period.

6.3 The young worker project took place at a time when sociology was expanding rapidly and moving away from the concerns of previous generations. Thus in the interviewer notes we see traces of a modern sociological approach encouraging the researchers to be reflexive in their practice whilst simultaneously remaining firmly anchored in 'an older version of social research, where interests in inequality and stratifications were rooted in community studies' (Savage, 2005:39). Like Goldthorpe et al., (1969) Elias's project team were encouraged to make detailed ethnographic accounts of the home environment of respondents and although these were not used by the researchers themselves, these notes are of incredible value for later researchers revealing much insight and promise for current social research.

\section{References}

ASHTON, D. and FIELD, D. (1976) Young Workers. London: Hutchinson.

BELL, C. and NEWBY, C. (1978) Community Studies. An Introduction to the Sociology of the Local Community, London: Allen and Unwin.

BROWN, A.E. (1970) The Growth of Leicester. Leicester: Leicester University Press.

CROMPTON, R. and HARRIS, F. (1998) 'Explaining Women's Employment Patterns: 'Orientations to Work' revisited'. British Journal of Sociology, Vol. 49, Issue 1, pp.118-136. [doi:10.2307/591266]

CROW, G. and ALLAN, G. (1990) Constructing the Domestic Sphere: The Emergence of the Modern Home in Post-War Britain, chapter 2 in Corr, H. and Jamieson, L. (Eds.) Politics of Everyday Life: Continuity and Change in Work and the Family, Basingstoke: Macmillan.

CROW, G. (2002) 'Community Studies: Fifty Years of Theorization' Sociological Research Online, Vol. 7 , No. 3, <http://www.socresonline.org.uk/7/3/crow.html> [doi:10.5153/sro.742]

DALE, A., ARBER, S., and PROCTER, M. (1988). Doing Secondary Analysis. London: Unwin Hyman.

ELIAS, N. (1939) Über den Prozess der Zivilisation. Basel: Haus zum Falker.

ELIAS, N. (1963) Unpublished Letter to llya Neustadt, $18^{\text {th }}$ January 1963. Marbach: Deutsches Literaturarchiv.

ELIAS, N. (1964) Unpublished Letter to llya Neustadt, $13^{\text {th }}$ March 1964. Marbach: Deutsches Literaturarchiv.

ELIAS, N. and SCOTSON, J. (1965) The Established and the Outsiders. London: Frank Cass.

ELIAS, N. (1974) 'Foreword: Towards a Theory of Communities' in C. Bell and H. Newby (editors) The Sociology of Community. London: Frank Cass, pp.ix-xli.

ELIAS, N. (1987) Retreat of the Sociologists, Theory, Culture and Society, Vol. 4, pp 223-247. [doi:10.1177/026327687004002003]

ELIAS, N. (1994) The Civilising Process. London: Basil Blackwell

ELIAS, N. (2001) The Society of Individuals. New York: Continuum Publishing.

FIELDING, N. (2000). The shared fate of two innovations in qualitative methodology: The relationship of qualitative software and secondary analysis of archived qualitative data. Forum Qualitative Sozialforschung /Forum: Qualitative Social Research, 1(3). Retrieved on August 6, 2002 from, $<$ http://www.qualitative-research.net/fqs-texte/3-00/3-00fielding-e.htm>

FIELDING, N. (2004) getting the most from archived qualitative data: epistemological, practical and professional obstacles. International Journal of Social Research Methodology, Vol. 7, No. 1, pp. 97-104. [doi:10.1080/13645570310001640699]

FINCH, J. (2007) Displaying Families. Sociology, Vol 41, No. 1, pp. 65-81 [doi:10.1177/0038038507072284]

GILLIES, V. (2003) Family and Intimate Relationships: A Review of the Sociological Research. Families and Social Capital ESRC Working Paper, London South Bank University.

<http://www.Isbu.ac.uk/families/workingpapers/familieswp2.pdf>

GOLDTHORPE, J., LOCKWOOD, D., BECHHOFER, F. and PLATT, J. (1969) The Affluent Worker in the Class Structure. Cambridge: Cambridge University Press.

GOODWIN, J. and O'CONNOR, H. (2006a) Norbert Elias and the Lost Young Worker Project Journal of Youth Studies, Vol. 9, No. 2, pp 159-173.

GOODWIN, J. and O'CONNOR, H. (2006b) Contextualising the Research Process: Using Interviewer Notes in the Secondary Analysis of Qualitative Data. The Qualitative Report, Volume 11, No 2,

<http://www.nova.edu/ssss/QR/QR11-2/goodwin.pdf> 
HAMMERSLEY, M. (1997) Qualitative Data Archiving: Some Reflections on its Prospects and Problems, Sociology, 31: 131-42. [doi:10.1177/0038038597031001010]

HARRIS, C., CHARLES, N., and DAVIES, C. (2006) Social Change and the Family Sociological Research Online, Volume 11, Issue 2, <http://www.socresonline.org.uk/11/2/harris.html>.

HEATON, J. (2004) Reworking Qualitative Data. London: Sage.

INNES, S. and MCKIE, L. (2006) 'Doing What is Right': Researching Intimacy, Work and Family Life in Glasgow, 1945-1960, Sociological Research Online, Vol. 11, Issue 2,

$<$ http://www.socresonline.org.uk/11/2/innes.html>

JACKSON, B. and MARSDEN, D. (1966) Education and the Working Class. (Second Edition) Aylesbury: Pelican.

LAUB, J. H. and SAMPSON, R.J. (2003) Shared Beginnings, Divergent Lives: Delinquent Boys to Age 70. Harvard: Harvard University Press.

LEICESTER CITY COUNCIL (1963) Minutes of Proceedings of the Council 22 ${ }^{\text {nd }}$ May 1963 to $30^{\text {th }}$ April 1963. Leicester: Leicester City Council.

MENNELL, S. (1992) Norbert Elias: An Introduction. Oxford: Blackwell.

O'CONNOR, H. and GOODWIN, J. (forthcoming) Utilising Data from a Lost Sociological Project:

Experiences, Insights, Promises. Qualitative Research.

PYE, N. (1972) Leicester and Its Region. Leicester: Leicester University Press.

SAVAGE, M. (2005). Revisiting Classic Qualitative Studies [43 paragraphs]. Forum Qualitative Sozialforschung / Forum: Qualitative Social Research, 6(1), Art. 31, <http://nbnresolving.de/urn:nbn:de:0114-fqs0501312>.

SMART, C. and NEALE, B. (1999) Family Fragments? Cambridge: Polity.

STACEY, M. (1960) Tradition and Change: A Study of Banbury. Oxford: Oxford University Press.

WOLFINGER, W. H. (2002). On writing field notes: Collection strategies and background expectancies. Qualitative Research, Volume 2, No. 1, pp 85-95. [doi:10.1177/1468794102002001640]

YOUNG, M. and WILLMOTT, P. (1957) Family and Kinship in East London. London: Routledge and Kegan Paul.

YOUNG WORKER PROJECT (1962) Minutes of Second Meeting 7 March 1962, Unpublished, Marbach: Deutsches Literaturarchiv. 